\title{
Effects of New Funding Models for Patient-Centered Medical Homes on Primary Care Practice Finances and Services: Results of a Microsimulation Model
}

Sanjay Basu, MD, $P b D^{1,2}$

Russell S. Pbillips, $M D^{2,3}$

Zirui Song, $M D, P b D^{2,4}$

Bruce E. Landon, MD, MBA, MSc $c^{2,3,5}$

Asaf Bitton, MD, MPH ${ }^{2,5-7}$

'Department of Medicine, Stanford University, Stanford, California

${ }^{2}$ Center for Primary Care, Harvard Medical School, Boston, Massachusetts

${ }^{3}$ Division of General Medicine and Primary Care, Beth Israel Deaconess Medical Center, Boston, Massachusetts

${ }^{4}$ Department of Medicine, Massachusetts General Hospital, Boston, Massachusetts

${ }^{5}$ Department of Health Care Policy,

Harvard Medical School, Boston,

Massachusetts

${ }^{6}$ Division of General Medicine, Brigham and Women's Hospital, Boston,

Massachusetts

${ }^{7}$ Ariadne Labs, Brigham and Women's Hospital, and Harvard T.H. Chan School of Public Health, Boston, Massachusetts

Conflicts of interest: Asaf Bitton serves part-time as a senior advisor to the Comprehensive Primary Care initiative at the Center for Medicare and Medicaid Innovation (CMMI).

\section{CORRESPONDING AUTHOR}

Sanjay Basu, MD, PhD

Medical School Office Building, X322

Stanford University School of Medicine

1265 Welch R, Mail Code 5411

Stanford, CA 94305-5411

basus@stanford.edu

\begin{abstract}
PURPOSE We assess the financial implications for primary care practices of participating in patient-centered medical home (PCMH) funding initiatives.
\end{abstract}

METHODS We estimated practices' changes in net revenue under 3 PCMH funding initiatives: increased fee-for-service (FFS) payments, traditional FFS with additional per-member-per-month (PMPM) payments, or traditional FFS with PMPM and pay-for-performance (P4P) payments. Net revenue estimates were based on a validated microsimulation model utilizing national practice surveys. Simulated practices reflecting the national range of practice size, location, and patient population were examined under several potential changes in clinical services: investments in patient tracking, communications, and quality improvement; increased support staff; altered visit templates to accommodate longer visits, telephone visits or electronic visits; and extended service delivery hours.

RESULTS Under the status quo of traditional FFS payments, clinics operate near their maximum estimated possible net revenue levels, suggesting they respond strongly to existing financial incentives. Practices gained substantial additional net annual revenue per full-time physician under PMPM or PMPM plus P4P payments ( $\$ 113,300$ per year, $95 \% \mathrm{Cl}, \$ 28,500$ to $\$ 198,200$ ) but not under increased FFS payments $(-\$ 53,500,95 \% \mathrm{Cl},-\$ 69,700$ to $-\$ 37,200)$, after accounting for costs of meeting PCMH funding requirements. Expanding services beyond minimum required levels decreased net revenue, because traditional FFS revenues decreased.

CONCLUSIONS PCMH funding through PMPM payments could substantially improve practice finances but will not offer sufficient financial incentives to expand services beyond minimum requirements for $\mathrm{PCMH}$ funding.

Ann Fam Med 2016;14:404-414. doi: 10.1370/afm.1960.

\section{INTRODUCTION}

A s of 2014 at least 114 distinct initiatives from state, federal, and private payers funded primary care clinics to offer services as patient-centered medical homes (PCMHs) - practices delivering comprehensive care for most health problems; coordinating care among multiple clinicians; and achieving heightened standards for accessibility, quality, and safety. ${ }^{1-4}$ These initiatives, which now involve at least 21 million patients in the United States ${ }^{4}$ intend to improve access and quality while delivering population-based care at lower cost..$^{1-3}$ To do so amidst workforce constraints, practices face challenges, including adopting process improvement techniques and electronic registries for care management, expanding care teams, offering patients longer in-person visits and access to electronic or telephone visits, and extending night and/or weekend business hours to enhance care access. ${ }^{1,5-8}$ According to recent national surveys, 3 major payment strategies have dominated PCMH initiatives: increased fee-for-service (FFS) payments, traditional FFS payments with additional per-member-per-month (PMPM) payments, and 
traditional FFS payments with PMPM and pay-forperformance (P4P) payments. ${ }^{4,7}$

To date, studies of PCMH performance have tracked patient outcomes and total medical spending, with generally positive quality but mixed cost results. ${ }^{9-19} \mathrm{An}$ unaddressed question, however, is how current $\mathrm{PCMH}$ funding models affect the financial sustainability of primary care practices and particularly whether current PCMH payment initiatives provide sufficient incentives for meaningful practice transformation. One emerging concern is that practices may minimally reform delivery in response to $\mathrm{PCMH}$ payment requirements while still pursuing a practice model that maximizes traditional FFS revenue. ${ }^{20,21}$ Here, we estimate the revenue and cost implications to primary care practices of delivering services funded by $\mathrm{PCMH}$ payment initiatives.

\section{METHODS}

We used a previously validated microsimulation model of primary care practices ${ }^{22,23}$ to estimate practice-level changes in net annual revenue after PCMH transformation under each of 3 dominant payment approaches supporting $\mathrm{PCMH}$ transformation. (increased FFS, PMPM, or PMPM plus $\mathrm{P} 4 \mathrm{P}$ ).

\section{Microsimulation Model}

Our model combines (1) a patient-level simulation of patients attending primary care clinics with (2) a practicelevel simulation of revenues and costs of service delivery to each clinic (Figure 1). The model was populated by sampling from detailed clinic utilization, revenue, and cost data from national surveys of primary care clinics, including clinics before and after PCMH transformation (Table 1). By structuring the model as a microsimulation, we account for the covariance between practice characteristics and patient characteristics, including billing practice variations. Comprehensive details are provided in the Supplemental Appendix (http://www.annfammed.org/ content/14/5/404/suppl/DC1).
At the patient level, the model simulates representative populations of each state and Washington, DC, ${ }^{24}$ and insurance coverage estimates among each population subsequent to the Patient Protection and Affordable Care $\mathrm{Act}^{33}$ (Supplemental Appendix Table 1, http://www.annfammed.org/content/14/5/404/ suppl/DC1). Based on age, sex, race/ethnicity, income, and insurance status, the model assigns diagnoses to each individual (by International Classification of DiseaseNinth Revision) to reflect the distribution of diagnoses (including comorbidities) across demographic groups, ${ }^{25}$ then estimates the number of outpatient visits and payments to clinics associated with these visits. ${ }^{25}$ Payment estimates account for geographic variations in billing and reimbursement by clinician and payer.

At the practice level, the model estimates visits and payments to primary care practices per year using national survey data. ${ }^{26}$ The model calculates practice costs for both personnel (staffing ratios and staff salaries per full-time physician $)^{28}$ and overhead expendi-
Figure 1. Model flow diagram.

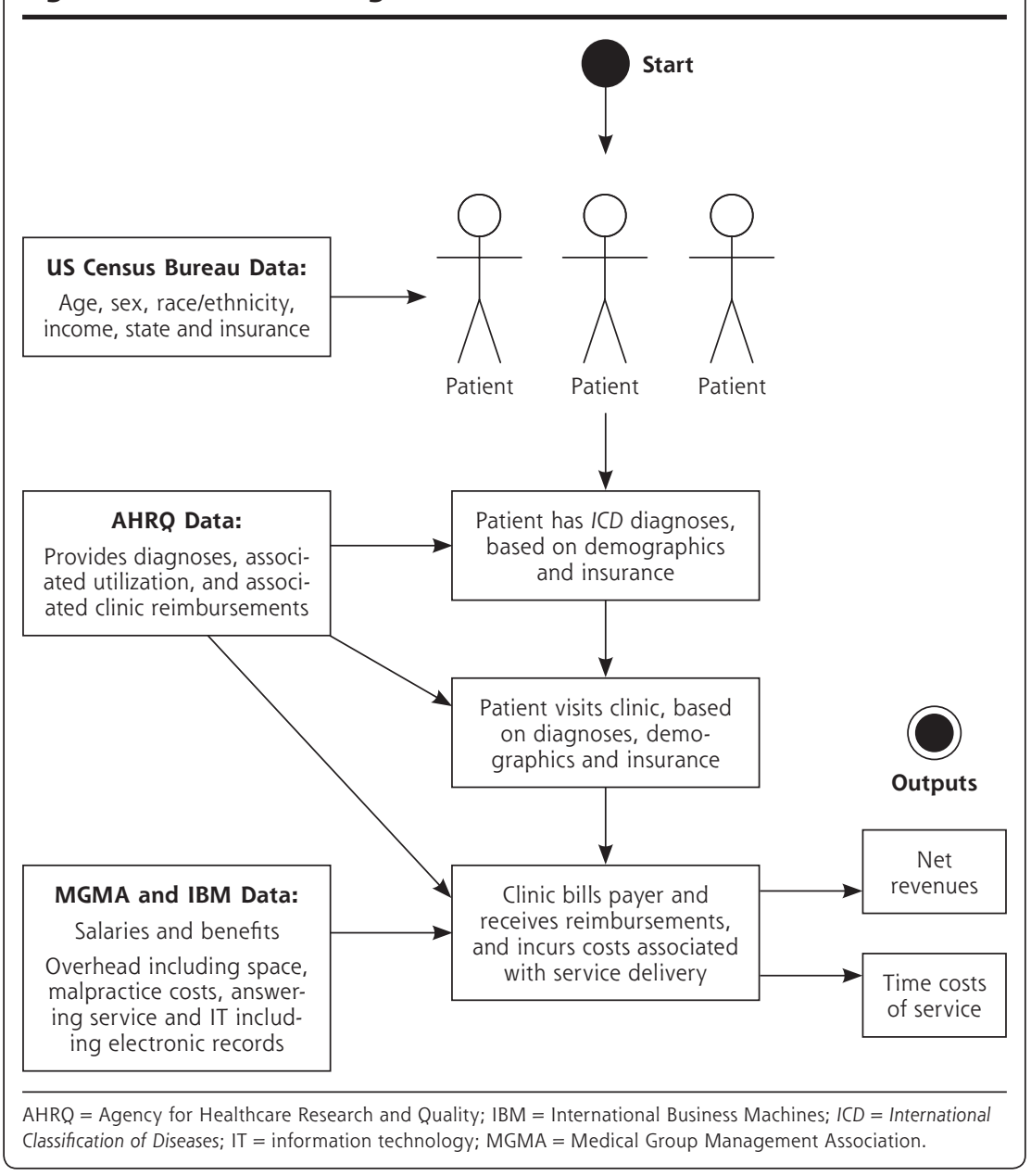


tures (staff benefits, building/occupancy, information technology, medical supply equipment, administrative supplies, liability insurance and fees, laboratory and imaging fees, and other ancillary service costs) ${ }^{34}$ (Supplemental Appendix Table 2, http://www.annfammed. org/content/14/5/404/suppl/DC1). All revenues and costs are expressed in 2015 US dollars using the Consumer Price Index to adjust for inflation. ${ }^{35}$

For validation, we ensured our model's estimates of utilization, cost, and revenue were within 5\% error of independent survey data ${ }^{36}$ and revenue and cost data among both pretransformation ${ }^{37}$ and posttransforma-

\section{Table 1. Data Inputs to the Model}

\begin{tabular}{|c|c|c|}
\hline Parameter & Details & Source \\
\hline \multicolumn{3}{|c|}{ Population demographics within each state population } \\
\hline Age, y & Cohorts of $<5,5-13,14-17,18-24,25-44,45-64,65-84$, and $>84 y$ & \multirow[t]{4}{*}{ US Census Bureau ${ }^{24}$} \\
\hline Sex & Cohorts of male or female & \\
\hline Race/ethnicity & $\begin{array}{l}\text { Cohorts of non-Hispanic white, non-Hispanic black, Hispanic, } \\
\text { and other }\end{array}$ & \\
\hline Insurance status & Cohorts of private, Medicare, Medicaid/CHIP, or self-pay & \\
\hline \multicolumn{3}{|l|}{ Patient features } \\
\hline Diagnoses among each demographic group & International Classification of Disease, Ninth Revision & \multirow{2}{*}{$\begin{array}{l}\text { Agency for Healthcare } \\
\text { Research and Quality }{ }^{25}\end{array}$} \\
\hline Per-person utilization of primary care clinics & $\begin{array}{l}\text { Visits per person per year, conditional on demographics, diagno- } \\
\text { ses, and state of residence }\end{array}$ & \\
\hline \multicolumn{3}{|l|}{ Practice features } \\
\hline $\begin{array}{l}\text { Productivity of primary care physicians } \\
\text { and midlevel clinicians }\end{array}$ & $\begin{array}{l}\text { Encounters and empanelment per clinician per year, by clinician } \\
\text { type (physician, NP, PA) }\end{array}$ & $\begin{array}{l}\text { Medical Group Manage- } \\
\text { ment Association }\end{array}$ \\
\hline $\begin{array}{l}\text { Utilization changes associated with } \\
\text { changes in staff }\end{array}$ & $\begin{array}{l}\text { Changes in encounters and empanelment given levels of support } \\
\text { staffa }\end{array}$ & \\
\hline $\begin{array}{l}\text { Staffing ratios of midlevel clinicians and } \\
\text { support staff per full-time physician }\end{array}$ & Including NPs, PAs, RNs, LPNs, and MAs & \\
\hline Overhead costs & $\begin{array}{l}\text { Including staff benefits, building and occupancy, information } \\
\text { technology, drug and medical supply, equipment and admin- } \\
\text { istrative supplies, liability insurance and fees, laboratory and } \\
\text { imaging fees, and other ancillary service costs }\end{array}$ & \\
\hline Compensation costs for clinician & Salary per full-time physician or midlevel clinician per year & Bureau of Labor Statistics ${ }^{27}$ \\
\hline Compensation costs for support staff & Salary per full-time worker per year, by worker type & $\begin{array}{l}\text { IBM Kenexa Compensa- } \\
\text { tion Analysis } 28\end{array}$ \\
\hline \multicolumn{3}{|l|}{ New financing approaches } \\
\hline PMPM payment rates & $\begin{array}{l}\text { Median of } \$ 4.90 \text { per empaneled patient per month }(95 \% \mathrm{Cl} \text {, } \\
\$ 3.00-\$ 8.00)\end{array}$ & $\begin{array}{l}\text { Survey of patient-centered } \\
\text { medical home initiatives }{ }^{4}\end{array}$ \\
\hline P4P payment rates & $\begin{array}{l}\text { Median receipt rate of } \$ 2.63 \text { per empaneled patient per annum } \\
\quad(95 \% \mathrm{Cl}, \$ 1.08-\$ 4.17)^{c}\end{array}$ & $\begin{array}{l}\text { National Academy for } \\
\text { State Health Policy }\end{array}$ \\
\hline $\begin{array}{l}\text { Empanelment rate among new patient } \\
\text { encounters (to charge new PMPM fees } \\
\text { during panel expansion) }\end{array}$ & $\begin{array}{l}\text { Median of } 53 \% \text { of new encounters ( } 95 \% \mathrm{Cl}, 42 \%-64 \%) \text { who } \\
\text { become additional panel members }\end{array}$ & $\begin{array}{l}\text { Medical Group Manage- } \\
\text { ment Association }{ }^{26}\end{array}$ \\
\hline $\begin{array}{l}\text { Reimbursement codes for electronic and } \\
\text { telephone visits }\end{array}$ & $\begin{array}{l}99444 \text { for electronic, } 99441 \text { for telephone, varied by state } \\
\text { and payer }\end{array}$ & $\begin{array}{l}\text { Center for Connected } \\
\text { Health Policy }\end{array}$ \\
\hline $\begin{array}{l}\text { Additional infrastructure costs for electronic } \\
\text { visits }\end{array}$ & $\$ 240$ per year $(95 \% \mathrm{Cl}, \$ 0-\$ 360)$ & $\begin{array}{l}\text { Telehealth Resource } \\
\text { Center }^{31}\end{array}$ \\
\hline Encounter rate per extended business hour & Regression model of utilization per extended hour ${ }^{d}$ & $\begin{array}{l}\text { Agency for Healthcare } \\
\text { Research and Quality }\end{array}$ \\
\hline \multicolumn{3}{|c|}{$\begin{array}{l}\text { CHIP = Children's Health Insurance Program; CPT = Current Procedural Terminology; FFS = fee for service; IBM = International Business Machines; LPN = licensed practical } \\
\text { nurse; } \mathrm{MA}=\text { medical assistant; NP = nurse practitioner; PA = physician assistant; P4P = pay for performance; PMPM = per-member-per-month; RN = registered nurse. }\end{array}$} \\
\hline \multicolumn{3}{|c|}{$\begin{array}{l}\text { Note: See Supplemental Appendix Tables } 1 \text { and } 2 \text { and Supplemental Appendix Figure } 1 \text { for full parameter values, http://www.annfammed.org/content/14/5/404/suppl/ } \\
\text { DC1. }\end{array}$} \\
\hline \multicolumn{3}{|c|}{ a See the Supplemental Appendix Figure 1, http://www.annfammed.org/content/14/5/404/suppl/DC1. } \\
\hline \multicolumn{3}{|c|}{$\begin{array}{l}{ }^{b} \text { Confidence intervals are estimates of the distribution of input data, not the results of a model of population data estimates, and are used to construct normal prob- } \\
\text { ability distributions from which to perform repeated sampling in our probabilistic uncertainty analyses. }\end{array}$} \\
\hline \multicolumn{3}{|c|}{$\begin{array}{l}\text { ' Receipt rate incorporates the observed rate of performance target achievement, which we varied in sensitivity analyses from a baseline estimate of } 10 \% \text { to a lower } \\
\text { and upper bound of } 0 \% \text { to } 100 \% .32\end{array}$} \\
\hline
\end{tabular}


tion $^{38}$ primary care clinics (Supplemental Appendix Figure 2, http://www.annfammed.org/content/14/5/404/ suppl/DC1 ).

\section{PCMH Simulation}

We first calculated the changes in costs and revenues per full-time equivalent (FTE) physician if practices changed minimally to meet criteria for new $\mathrm{PCMH}$ funding (base case), then estimated what changes to service delivery would maximize net revenues under the new PCMH funding approaches. To provide optimistic financial sustainability estimates for PCMHs, we did not include highly variable up-front costs of transformation in our base-case simulation, ${ }^{39}$ only the costs to maintain $\mathrm{PCMH}$ functions after transformation. Furthermore, we defined the minimum criteria to match the standards accepted for $\mathrm{PCMH}$ financing by payers responding to a previous national PCMH survey, ${ }^{4}$ which included basic (level 1) PCMH standards for accreditation by the National Committee for Quality Assurance (NCQA) and accreditation by other major agencies, including the Utilization Review Accreditation Commission and the Joint Commission. The criteria were not limited to NCQA level 3 recognition because many PCMH payment initiatives have been funding practices as $\mathrm{PCMHs}$ despite not meeting level 3 criteria; with the more inclusive definition, our results favor PCMH maintenance (ie, does not inflate our cost estimates). Typical staff ratios among practices meeting PCMH criteria were obtained from a survey of 502 practices in 7 regions. ${ }^{40}$

Minimum costs of PCMH maintenance included physical infrastructure charges for patient tracking, quality improvement, communications, and related infrastructure, averaging in 2015 US dollars $\$ 2.51$ per patient per month $(95 \% \mathrm{CI}, \$ 0.95-\$ 4.57)$ estimated from a national survey of 1,009 practices $^{38}$ (updated from $\$ 2.26$ in 2009 dollars using the Consumer Price Index, not significantly different from the estimate of $\$ 2.08,95 \% \mathrm{CI}, \$ 0.58-\$ 4.83$, from a more limited survey of 20 practices, excluding one-time transformation costs, ${ }^{39}$ and estimates from smaller surveys in Utah [8 practices, \$3.85] and Colorado [12 practices, \$4.83]). ${ }^{41}$ Salaries and overhead costs incurred for support staff were incorporated into all cost tabulations (Supplemental Appendix and Table 1), whereas the effects of support staff on clinic efficiency and productivity (eg, through extended team roles) were incorporated by Monte Carlo sampling from the probability distribution of encounters and revenue associated with different staffing ratios ${ }^{26}$ (Supplemental Appendix Figure 1, http://www.annfammed.org/content/14/5/404/suppl/ DC1). As an additional check of face validity, our estimates for PCMH monthly maintenance costs per 1 FTE physician were approximately $\$ 70,750$ (95\% CI,
$\$ 10,670-\$ 51,320)$, not significantly different from the independent estimate of $\$ 64,768$ per year $(95 \% \mathrm{CI}$, $18,585-\$ 83,856$ ) from a recent survey of 12 practices. ${ }^{39}$

FFS revenues were assigned for each visit according to Table 1. Median PMPM rates, obtained from a national survey of $\mathrm{PCMH}$ funding initiative participants (Table 1), ${ }^{4}$ were multiplied by the number of empaneled patients, estimated as the number of encounters multiplied by the ratio of empaneled patients to encounters (median of $53 \%$ of visits are empaneled, $95 \% \mathrm{CI}$, $42 \%$ to $64 \%$, per national practice surveys [Table 1 , and increased in sensitivity analyses). ${ }^{26} \mathrm{P} 4 \mathrm{P}$ bonuses (Table 1) were distributed at the mean achievement rate of approximately $10 \%$ (also increased in sensitivity analyses). ${ }^{32}$

We next estimated changes in revenues and costs if practices offered PCMH functionality beyond minimum levels required for funding by increasing the staffing ratios above the minimum levels observed in a survey of 502 transforming practices across the nation ${ }^{40}$ and by altering visit templates and service hours as anticipated under the PCMH model. Visit template alterations included (1) extending visit length by $5 \mathrm{~min}$ utes, lowering overall visit volume per day but using higher billing codes that reflected more time spent per patient; or (2) converting $10 \%$ of routine follow-up visits to electronic or telephone visits (reimbursed per payer-specific rates for CPT [Current Procedural Terminology] code 99444 for 10-minute electronic visits, or 99441 for 10 -minute telephone visits), and adding 5 minutes documentation time and infrastructure costs (Table 1). ${ }^{30,31,42}$ Shifting established patients to electronic or telephone visits enabled practices to open appointment slots for new and established patients. We distributed the open slots among new vs established patients in the same ratio as existing visit ratios at each clinic. Extended service hours included evening and weekend business hours during which the typical number of visits per hour was estimated from the Medical Expenditure Panel Survey (Table 1) ${ }^{25}$; costs of extending service hours included staff compensation for a physician or nurse practitioner, plus hourly overhead costs including support staff for the clinician, building space, and utility costs (Supplemental Appendix Table 2). ${ }^{26}$

\section{Optimization}

We performed an optimization analysis to identify what changes to support staff, visit templates, and service delivery hours would maximize net revenue before and after PCMH transformation. A generalized pattern search algorithm was used to repeatedly run the model across all possible combinations of staff, visit, and delivery hour changes to maximize net revenue per FTE physician under each payment approach. ${ }^{43}$ 


\section{Break-Even Analysis}

We estimated the probability that a PCMH would maintain positive net revenue after several possible service delivery changes: if adding 1 FTE for each type of support staff (care coordinator, registered nurse $[\mathrm{RN}]$, licensed practical nurse [LPN], or medical assistant $[\mathrm{MA}]$ ) if adding 5 minutes to each visit (with coding also increased 1 level for these longer visits), if converting $10 \%$ of in-person visits to telephone or electronic visits, or if adding 1 business day equivalent ( 8 hours of evening/weekend service) per week in a practice of 5 FTE physicians (the median practice size). The probability was calculated by running the model 10,000 times, drawing repeatedly from the range of each input parameter (Supplemental Appendix Table 2 and Supplemental Appendix Figure 1) to estimate the frequency with which the clinic achieved positive net revenues after each service delivery change. ${ }^{44}$

\section{Sensitivity Analyses}

In sensitivity analyses, we varied the $\mathrm{P} 4 \mathrm{P}$ bonus achievement rate (to $100 \%$ ). We also varied PCMH payment rates, service delivery costs, and patient utilization rates from $80 \%$ to $120 \%$ of their base-case values (Table 1). We further investigated whether PCMH transformation produced such clinical efficiency that costs of PCMH maintenance became negative (a net cost savings) at up to $\$ 5$ saved per patient per month. We explored the impact of risk-adjusting PMPM rates using the algorithm utilized by the Centers for Medicare and Medicaid Services. ${ }^{45}$ Finally we performed subgroup analysis by state to identify geographic variations in net revenue (Supplemental Appendix).

All analyses were performed in $R$ (v. 3.1.2, The $R$ Foundation for Statistical Computing).

\section{RESULTS}

In the primary data sources used to populate the model, median gross annual revenues among primary care practices were $\$ 487,390$ per year from standard FFS payments $(95 \% \mathrm{CI}, \$ 205,231-\$ 955,765)$ from a total of $\$ 871,069$ in charges $(95 \% \mathrm{CI}, \$ 365,54$ $\$ 1,749,134)$ per FTE physician. ${ }^{26}$ Based on these gross revenues, costs of clinic operations per FTE physician, including physician and support staff salaries and benefits, material costs, and overhead expenditures, totaled $\$ 443,569$ (95\% CI, $\$ 182,882-\$ 876,449)$ per year. ${ }^{26}$

\section{Financial Outcomes Before Medical Home Transformation}

Before PCMH transformation, practice revenue optimization did not require major modifications to baseline support staffing ratios, visit templates, or service delivery hours to maximize net annual revenues from traditional FFS payments. The staffing ratios that maximized net revenues included 0 FTEs for a care coordinator, 0.45 FTEs for RNs, 0.78 FTEs for LPNs, and 1.25 FTEs for MAs per 1 FTE physician (Supplemental Appendix). Visit duration did not increase, nor were electronic or telephone visits included (because of lost FFS revenue from routine office visit volume; Table 2). Evening and weekend business hours increased slightly (to 2.7 evening or weekend hours per week), beyond which overhead and staffing costs exceeded expected revenues from extended business hours.

\section{Financial Outcomes After Medical Home Transformation}

Under current types of PCMH funding initiatives, practices experienced increases in gross annual revenue of $\$ 55,700$ to $\$ 222,500$ when only minimally reforming their staffing ratio and infrastructure to meet funding requirements (Table 2). At piloted rates of reimbursement, increased FFS financing generated the least revenue compared with PMPM or PMPM plus P4P. Net revenue under increased FFS financing was lower after PCMH transformation than under traditional FFS payments before $\mathrm{PCMH}$ transformation $(\$ 53,464$ lost per FTE physician per year, 95\% CI, \$37,203-\$69,725 lost). PMPM and PMPM plus P4P, by contrast, always resulted in net revenue gains compared with traditional FFS (Table 2 and Figure 2).

\section{Altered Staffing Ratios}

As shown in Table 2, increasing staff beyond the minimum required for $\mathrm{PCMH}$ funding reduced net revenue under all scenarios. The costs of salary, benefits, and overhead for staff exceeded the revenue benefits from increased efficiency and support from a greater number of staff members. Probabilistic sensitivity and uncertainty analyses across the range of observed minimum staffing levels (Table 1) did not alter this outcome.

\section{Altered Visit Templates}

Extending visit length or offering electronic or telephone visits reduced net revenue because of the staffing costs of implementation (Table 2). In the most revenue-generating scenario, where clinics adopted the PMPM plus P4P payment model, no new revenues were produced, but new annual costs of $\$ 168,700$ were incurred from extending visit length by 5 minutes (as a result of lost FFS revenue from forfeited visits).

\section{Extended Business Hours}

By contrast, extended business hours increased net revenues for practices. Under the increased FFS approach, net revenue was maximized by extending evening or 
weekend hours to 3.0 hours per week $(95 \% \mathrm{CI}, 2.7-3.2$ hours), whereas under both the PMPM and PMPM plus $\mathrm{P} 4 \mathrm{P}$ approaches, net revenue was maximized by increasing hours to 3.8 hours per week. At these levels, net revenues increased marginally by between $\$ 500$ and $\$ 1,000$ per year per FTE physician (Table 2). Beyond these extended hours levels, salary and overhead costs of each additional hour exceeded anticipated revenues.

\section{Break Even Analysis}

Figure 3 illustrates the probability that a clinic, after meeting minimum practice transformation requirements, would maintain positive net revenues after increasing support staff, altering visit templates, or extending service hours under the new PCMH financing approaches. The probability that the new $\mathrm{PCMH}$ funding could support the addition of 1 FTE care coordinator for a median practice size of 5 FTE physicians ranged from $0 \%$ under increased $\mathrm{FFS}$ to $89 \%(95 \% \mathrm{CI}$, 55\%-100\%) under PMPM plus P4P bonuses. The probability was low for supporting routine electronic or telephone visits (less than 5\%), and high for supporting extended business hours $(100 \%$ in all simulation scenarios).

\section{Sensitivity Analyses}

Sensitivity analyses did not produce significant changes to the staffing ratios, visit templates, or busi-

\section{Table 2. Model-Based Estimates of Changes in Net Revenue per Full-Time Physician for Primary Care Clinics Delivering PCMH Services Compared With the Net Revenue in the Traditional FFS Clinic Before PCMH Transformation}

\begin{tabular}{|c|c|c|c|c|c|}
\hline $\begin{array}{l}\text { Change in Net Revenue } \\
\text { (\$/FTE physician/year) }\end{array}$ & $\begin{array}{c}\text { Traditional FFS } \\
\$(95 \% \mathrm{CI})\end{array}$ & $\begin{array}{l}\text { Increased FFS } \\
\$(95 \% \mathrm{Cl})\end{array}$ & $\begin{array}{c}\text { PMPM } \\
\$(95 \% \mathrm{CI})\end{array}$ & $\begin{array}{l}\text { PMPM plus } \\
\text { P4P Bonuses } \\
\$(95 \% \mathrm{Cl})\end{array}$ & $\begin{array}{l}\text { Maximizing Net } \\
\text { Revenues Under PCMH } \\
\text { Payment Initiatives }\end{array}$ \\
\hline $\begin{array}{l}\text { Minimum required changes } \\
\text { for } \mathrm{PCMH} \text { funding }\end{array}$ & N/A & $\begin{array}{c}-53,464 \\
(-69,725 \text { to } \\
-37,203)\end{array}$ & $\begin{array}{c}103,835 \\
(24,462 \text { to } \\
183,208)\end{array}$ & $\begin{array}{c}113,343 \\
(28,511 \text { to } \\
198,176)\end{array}$ & $\mathrm{N} / \mathrm{A}$ \\
\hline \multicolumn{6}{|l|}{ Service delivery enhancements } \\
\hline Optimize staff ratiob & $\begin{array}{c}46,722 \\
(25,737 \text { to } \\
155,577)\end{array}$ & $\begin{array}{c}-53,464 \\
(-69,725 \text { to } \\
-37,203)\end{array}$ & $\begin{array}{c}103,835 \\
(24,462 \text { to } \\
183,208)\end{array}$ & $\begin{array}{c}113,343 \\
(28,511 \text { to } \\
198,176)\end{array}$ & $\begin{array}{c}\text { FTEs: } 0.23 \mathrm{CC}, 0.31 \mathrm{RN}, \\
0.53 \mathrm{LPN}, 1.11 \mathrm{MA}\end{array}$ \\
\hline Extend visit length by $5 \min ^{c}$ & $\begin{array}{c}-119,092 \\
(-170,874 \text { to } \\
-83,002)\end{array}$ & $\begin{array}{c}-184,925 \\
(-255,049 \text { to } \\
-149,057)\end{array}$ & $\begin{array}{c}-62,771 \\
(-156,974 \text { to } \\
-57,134)\end{array}$ & $\begin{array}{c}-55,390 \\
(-152,320 \text { to } \\
-52,719)\end{array}$ & Not in optimal result \\
\hline $\begin{array}{l}\text { Replace } 10 \% \text { of visits with } \\
\text { electronic visits }\end{array}$ & $\begin{array}{c}-16,175 \\
(-17,134 \text { to } \\
-15,165)\end{array}$ & $\begin{array}{c}-71,497 \\
(-83,935 \text { to } \\
-59,960)\end{array}$ & $\begin{array}{c}80,427 \\
(11,394 \text { to } \\
145,836)\end{array}$ & $\begin{array}{c}89,610 \\
(15,611 \text { to } \\
159,704)\end{array}$ & Not in optimal result \\
\hline $\begin{array}{l}\text { Replace } 10 \% \text { of visits with } \\
\text { telephone visits }\end{array}$ & $\begin{array}{c}-16,151 \\
(-17,107 \text { to } \\
-15,144)\end{array}$ & $\begin{array}{c}-71,473 \\
(-83,915 \text { to } \\
-59,931)\end{array}$ & $\begin{array}{c}80,451 \\
(11,413 \text { to } \\
145,868)\end{array}$ & $\begin{array}{c}89,634 \\
(15,629 \text { to } \\
159,736)\end{array}$ & Not in optimal result \\
\hline Extend evening/weekend hours & $\begin{array}{c}380(373 \text { to } \\
386)\end{array}$ & $\begin{array}{c}-52,959 \\
(-69,227 \text { to } \\
-36,692)\end{array}$ & $\begin{array}{c}104,781 \\
(25,402 \text { to } \\
184,160)\end{array}$ & $\begin{array}{c}114,321 \\
(29,482 \text { to } \\
199,159)\end{array}$ & $3.0-3.8 \mathrm{~h} / \mathrm{wk}$ \\
\hline $\begin{array}{l}\text { Net revenue-maximizing } \\
\text { combination }^{f}\end{array}$ & $\begin{array}{c}47,101 \\
(26,110 \text { to } \\
155,963)\end{array}$ & $\begin{array}{c}-52,959 \\
(-69,227 \text { to } \\
-36,692)\end{array}$ & $\begin{array}{c}104,781 \\
(25,402 \text { to } \\
184,160)\end{array}$ & $\begin{array}{c}11,4321 \\
(29,482 \text { to } \\
199,159)\end{array}$ & $\begin{array}{c}\text { FTEs: } 0.23 \mathrm{CC} \\
0.31 \mathrm{RN}, 0.53 \mathrm{LPN} \\
1.11 \mathrm{MA}+3.0-3.8 \mathrm{~h} / \mathrm{wk} \\
\text { evening/weekend service }\end{array}$ \\
\hline
\end{tabular}

$\mathrm{CC}=$ care coordinator; FFS = fee for service; $\mathrm{FTE}=$ full-time equivalent; $\mathrm{LPN}=$ licensed practical nurse; $\mathrm{MA}=$ medical assistant; $\mathrm{P} 4 \mathrm{P}=$ pay for performance; $\mathrm{PCMH}=$ patient-centered medical home; PMPM = per member per month; RN = registered nurse.

Note: Revenues include 4 funding scenarios: traditional FFS, increased FFS, PMPM, and PMPM plus P4P bonus. Confidence intervals in parentheses are from probabilistic sensitivity analyses in which the model was rerun 10,000 times while sampling from the probability distributions of all input parameters to generate confidence intervals around model results.

Meets basic criteria of PCMH funding initiatives, cataloged previously, ${ }_{1}^{4}$ incorporating changes in communication, care management, external coordination, patient tracking, test/referral tracking, and quality improvement at an inflation-adjusted cost of $\$ 2.51$ per patient per month $(95 \% \mathrm{Cl}, \$ 0.95-\$ 4.57) .{ }^{35}$ Staffing ratios include a minimum of 0.23 FTE for a CC (0.21-0.25), 0.31 FTE for an RN (0.28-0.34), 0.53 FTE for an LPN (0.50-0.56), and 1.11 FTE for an MA per FTE physician (1.09-1.13).40 Probabilistic sensitivity and uncertainty analyses performed across the listed Cls through repeated sampling from corresponding normal distributions of minimum staffing levels to assess robustness of results. All costs expressed in 2015 US dollars.

${ }^{b}$ Adjusted support staff (CC, RN, LPN, and MA) levels per full-time physician, determined by repeated sampling from observed joint probability distributions linking staffing levels across clinicians and support staff to encounters and empanelment (Supplemental Appendix Figure 1, http://www.annfammed.org/content/14/5/404/ suppl/DC1), then detecting which combinations of staffing levels maximized net revenue while still meeting the minimum PCMH funding requirements. Note that maximum net revenue was achieved by minimum staffing in all PCMH funding scenarios.

' Increasing visits by 5 minutes each from the baseline length at each simulated clinic.

Simulated as replacing $10 \%$ of regular in-person encounters.

e Optimization involved finding the number of evening or weekend hours per week that would maximize net revenues for the clinic, calculating medical revenue from each additional business hour of providing service availability during nights and weekends via a midlevel practitioner, and subtracting the costs of compensation and overhead expenditure for those hours.

f Includes optimized clinic activities in all above-mentioned domains. 
ness hours that maximized net revenues for clinics. Increasing the P4P bonus success rate from 10\% to $100 \%$ (Supplemental Appendix Table 3, http:// www.annfammed.org/content/14/5/404/suppl/DC1) increased net revenues by $\$ 88,900$ per FTE physician per year under the PMPM funding approach plus $\mathrm{P} 4 \mathrm{P}$ bonuses. Varying payment rates in each PCMH financing approach minimally changed the optimal number of extended business hours (Supplemental Appendix Tables 4-5, http://www.annfammed.org/ content/14/5/404/suppl/DC1). Under higher payment rates, altering visit templates to extend visit length or adding telephone or electronic visits generated greater losses to clinics than in the base case, because lost in-person visit revenue was greater. Varying service delivery costs and patient utilization rates produced minimal changes to revenue-maximizing number of extended business hours without otherwise altering the optimization results (Supplemental Appendix Tables 6-9, http://www.annfammed.org/content/14/5/404/ suppl/DC1). The optimization result also did not change whether PCMH maintenance produced net savings instead of costs, or whether PMPM rates were risk-adjusted (Supplemental Appendix Tables 10 and 11, http://www.annfammed.org/content/14/5/404/ suppl/DC1). Variations in patient population, billing

\section{Figure 2. Net revenue changes per full-time physician per year from clinics meeting minimum requirements to receive $\mathrm{PCMH}$ funding, as compared with the clinic operating under traditional fee-for-service payments.}

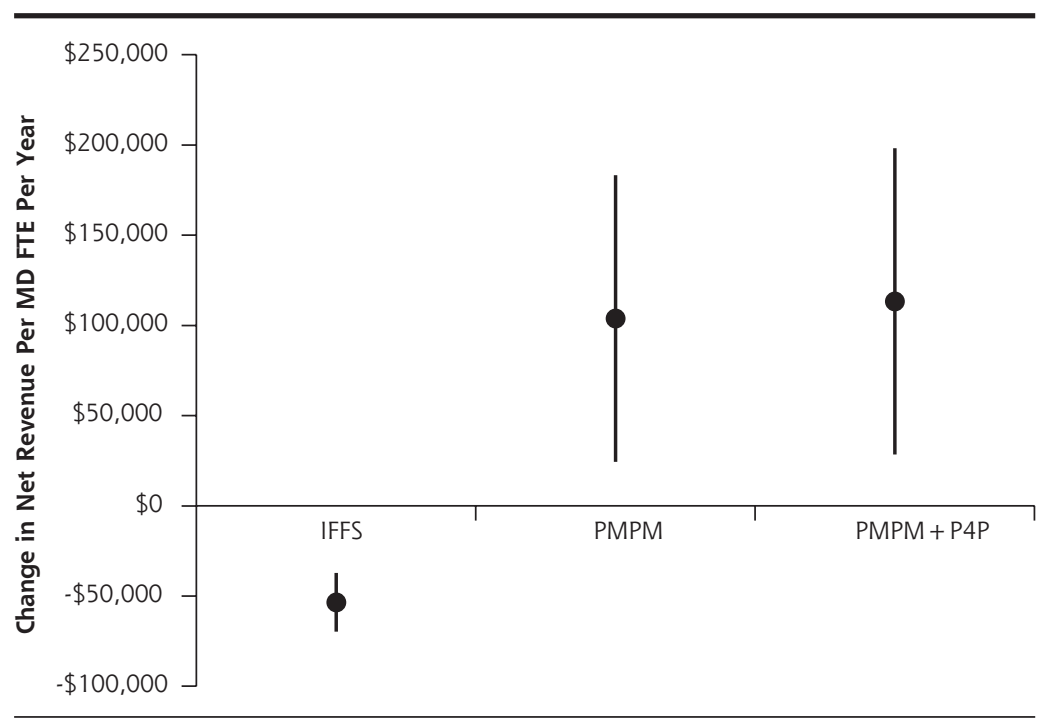

IFFS = increased fee for service; P4P = pay for performance; $\mathrm{PCMH}=$ patient-centered medical home; PMPM $=$ per-member-per-month.

Note: The PCMH funding approaches include IFFS rates, PMPM funding, and PMPM plus P4P bonuses (Table 1). The uncertainty ranges portrayed incorporate 3 sets of uncertainty through repeated sampling from the probability distributions of the input parameters: uncertainty in levels of utilization and associated revenue, cost to the practice including staff compensation and other practice costs, and payments through the new PCMH financing approaches (eg, level of payment increase from IFFS). behavior, and reimbursement rates by state did not change practice optimization, but they did produce as much as a $\$ 76,400$ /year per FTE physician difference states (Supplemental Appendix Table 12, http://www. annfammed.org/content/14/5/404/suppl/DC1)

\section{DISCUSSION}

Although investments in the PCMH should be informed by benefits to patient care, the decision at a practice level remains influenced by financial outcomes, particularly given the tenuous financial sustainability of many primary care practices. The goal of primary care practice is to improve patient care. PCMH transformation has the additional goal of increasing general investment in primary care. Achieving these goals requires financial sustainability over the near-term, but the costs of these goals have been prohibitive, and providing high-value care has in turn been limited.

Our model-based analyses suggest that if PCMH funding initiatives were expanded through current PMPM-based funding approaches (but not increased FFS at currently-piloted rates), primary care practices could expect to gain net revenue by participating in the initiatives. Although clinics under the traditional FFS payment system are operating near their revenue-maximizing levels of staffing and service delivery-suggesting that clinics are highly responsive to financial incentives - they would not gain additional revenues by investing incremental PCMH payments in increasing staff or altering visit templates beyond the minimally required levels to meet $\mathrm{PCMH}$ funding requirements. The costs of hiring additional clinic staff were not offset by increased clinic efficiency or workflow. Extending in-person visits or offering minimally or unreimbursed telephone or electronic visits resulted in lost revenue generated by traditional FFS office-based visits.

These findings contribute important new insights to the literature on PCMHs, explaining why some previous evaluations of PCMH demonstrations have shown mixed impact. Studies have not clearly established what factors determine whether PCMH 
Figure 3. Break even analysis, which identified the probability with which key medical home services could be supported by a clinic without achieving negative net revenue.

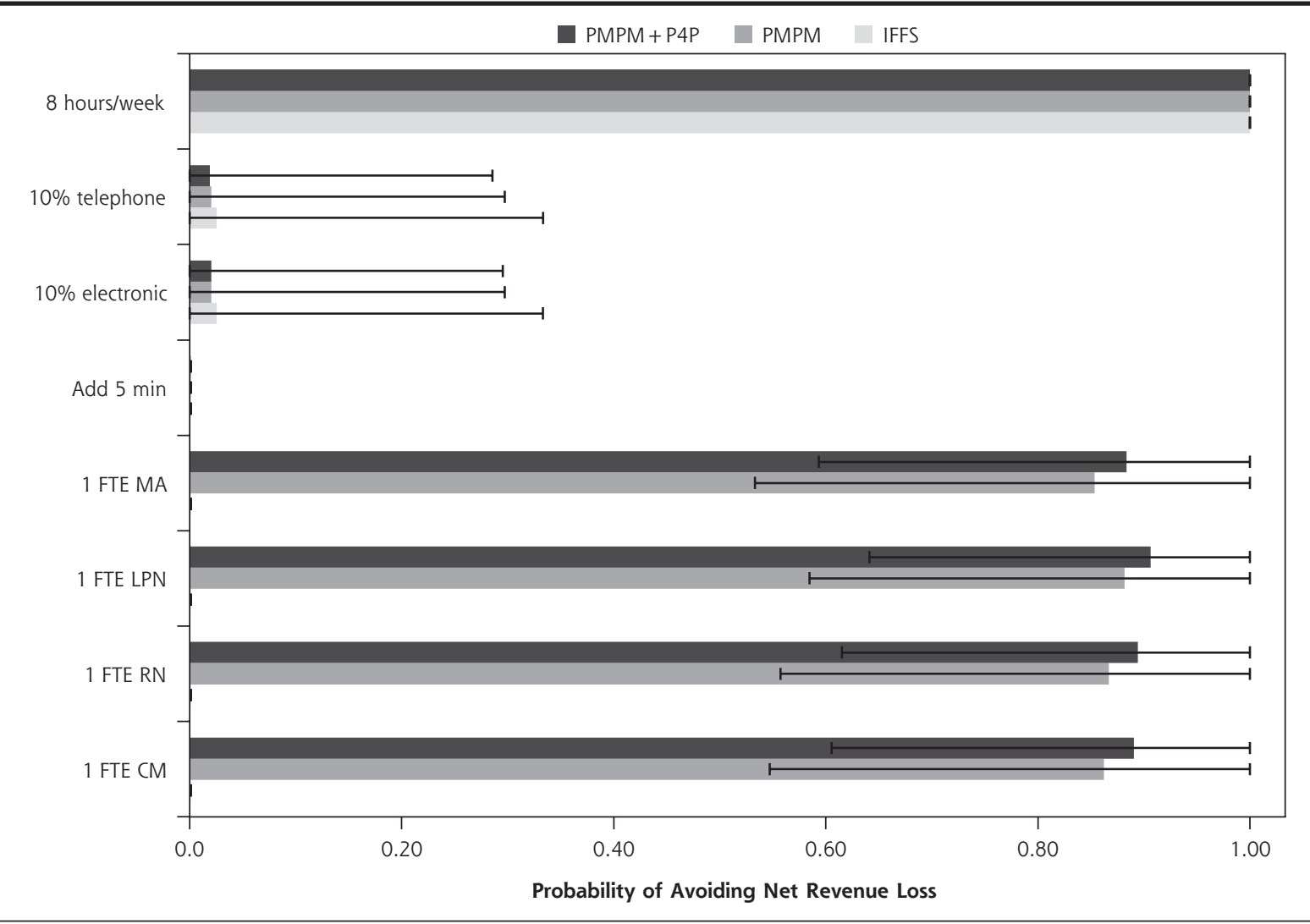

$C C=$ care coordinator; FTE = full-time equivalent; IFFS = increased fee for service; LPN = licensed practical nurse; $M A=$ medical assistant $;$ P4P = pay for performance; PMPM = per member per month; RN = registered nurse.

Note: We specifically calculated the probability that a clinic would not lose net revenue through the addition of 1 FTE for each type of support staff (CC, RN, LPN, and MA); when adding 5 minutes to each visit; when converting $10 \%$ of routine visits to electronic or telephone visits; or when adding 1 full business day ( 8 evening/weekend business hours) per week in a median practice size of 5 FTE physicians.

transformations are financially sustainable for practices. Our model suggests that although PCMH transformation initiatives have adopted a team-based delivery approach, ${ }^{14,15,46}$ more radical payment reforms may be required to adequately fund these changes at the practice level. Phrased differently, practices must receive more robust non-visit-based payment mechanisms to provide an incentive to sustain transformation. The recently announced Comprehensive Primary Care Plus model aims to promote this type of payment reform in its Track 2, which incorporates higher PMPM amounts, larger performance bonuses, and perhaps most importantly, upfront per capita population-based payments that offset gradual reductions in FFS reimbursements. ${ }^{47}$

Our study fills an important gap in the literature because existing demonstration-project evaluation efforts have focused on system-level cost savings (eg, through fewer emergency department or specialty visits), which have been inconsistently observed. ${ }^{10,14-16,18,48-62}$ For many practices, revenue gains must be observed at the practice level to justify practice-level workforce and time use changes. Another key advantage is that our modeling allows us to compare different reforms in the same practices, unlike demonstration projects for which it is unclear whether differences in outcomes are due to differences in the PCMH funding program itself or preexisting practice differences.

Our findings were robust to wide variations in levels of payment, cost, and clinic performance but have some important limitations. There are insufficient or no publicly available data on some new $\mathrm{PCMH}$ funding strategies, such as fully capitated payment, shared-savings programs, and the alternative payment model from Medicare. Our model will have to be extended as new payment strategies emerge with large-scale data. The number of staff required to meet $\mathrm{PCMH}$ requirements in the model was also based on a 
pilot study involving a limited sample size of practices that elected into transformation ${ }^{40}{ }_{i}$ nationwide, less ambitious or PCMH-ready clinics may require even more staff to assist in transformation, rendering our results conservative. Our results are also conservative because we examined the net revenue after transformation, not the costs of transformation itself, which remains highly variable.

Some clinics may choose to lose revenue in the interest of service enhancement, as long as they remain financially sustainable. Hence, we examined what levels of service would permit clinics to break even. Expanding business hours would be among the most revenuegenerating strategies for delivering PCMH services, consistent with earlier findings, ${ }^{63}$ and could be adopted sustainably under any of the $\mathrm{PCMH}$ funding initiatives. Notably, however, the current level of incentivized extended business hours were limited to about 3 hours per week, which may not be of important clinically.

Our model does not provide an answer to what practices should do, only what fiscal outcomes may occur after different decisions. We cannot predict health or experiential changes, which can be more directly assessed through traditional evaluation methods $^{3,6,64-72}$; hence, we focused on the financial implications of practice-level management decisions, which are often assessed through modeling.

In a microsimulation model of primary care practices, current PMPM-based funding for patientcentered medical homes may enhance finances for practices but offers only minimal incentives to change staffing ratios and service delivery strategies. Achieving goals of the $\mathrm{PCMH}$ will likely require more radical payment reforms specifically to target funding toward the delivery of desired services. To read or post commentaries in response to this article, see it
online at http://www.annfammed.org/content/14/5/404.

Key words: primary health care; models, theoretical; capitation fee; fee-for-service plans; patient-centered care

Submitted January 1, 2016; submitted, revised, April 4, 2016; accepted May 4, 2016.

Disclaimer: The ideas expressed herein are solely the authors' and do not represent any official position of the Center for Medicare and Medicaid Innovation.

Supplementary materials: Available at http://www.AnnFamMed. org/content/14/5/404/suppl/DC1/.

\section{References}

1. National Academy for State Health Policy. Medical Home \& PatientCentered Care Database. Portland, OR: NASHP; 2014.

2. Rittenhouse DR, Shortell SM. The patient-centered medical home: will it stand the test of health reform? JAMA. 2009;301(19): 2038-2040.
3. Ferrante JM, Balasubramanian BA, Hudson SV, Crabtree BF. Principles of the patient-centered medical home and preventive services delivery. Ann Fam Med. 2010;8(2):108-116.

4. Edwards ST, Bitton A, Hong J, Landon BE. Patient-centered medical home initiatives expanded in 2009-13: providers, patients, and payment incentives increased. Health Aff (Millwood). 2014;33(10):1823-1831.

5. Rosenthal TC. The medical home: growing evidence to support a new approach to primary care. J Am Board Fam Med. 2008;21(5): 427-440.

6. Jackson GL, Powers BJ, Chatterjee R, et al. Improving patient care. The patient centered medical home. A Systematic Review. Ann Intern Med. 2013;158(3):169-178.

7. Bitton A, Martin C, Landon BE. A nationwide survey of patient centered medical home demonstration projects. J Gen Intern Med. 2010;25(6):584-592.

8. Patel MS, Arron MJ, Sinsky TA, et al. Estimating the staffing infrastructure for a patient-centered medical home. Am J Manag Care. 2013;19(6):509-516.

9. Nelson KM, Helfrich $C$, Sun $\mathrm{H}$, et al. Implementation of the patientcentered medical home in the Veterans Health Administration: associations with patient satisfaction, quality of care, staff burnout, and hospital and emergency department use. JAMA Intern Med. 2014;174(8):1350-1358.

10. DeVries A, Li C-HW, Sridhar G, Hummel JR, Breidbart S, Barron JJ. Impact of medical homes on quality, healthcare utilization, and costs. Am J Manag Care. 2012;18(9):534-544.

11. Alexander JA, Bae D. Does the patient-centred medical home work? A critical synthesis of research on patient-centred medical homes and patient-related outcomes. Health Serv Manage Res. 2012;25(2):51-59.

12. Hebert PL, Liu C-F, Wong ES, et al. Patient-centered medical home initiative produced modest economic results for Veterans Health Administration, 2010-12. Health Aff (Millwood). 2014;33(6):980-987.

13. Han E, Hudson Scholle S, Morton S, Bechtel C, Kessler R. Survey shows that fewer than a third of patient-centered medical home practices engage patients in quality improvement. Health Aff (Millwood). 2013;32(2):368-375.

14. Bielaszka-DuVernay C. Vermont's Blueprint for medical homes, community health teams, and better health at lower cost. Health Aff (Millwood). 2011;30(3):383-386.

15. Harbrecht MG, Latts LM. Colorado's Patient-Centered Medical Home Pilot met numerous obstacles, yet saw results such as reduced hospital admissions. Health Aff (Millwood). 2012;31(9):2010-2017.

16. Raskas RS, Latts LM, Hummel JR, Wenners D, Levine H, Nussbaum SR. Early results show WellPoint's patient-centered medical home pilots have met some goals for costs, utilization, and quality. Health Aff (Millwood). 2012;31(9):2002-2009.

17. Rosenthal MB, Friedberg MW, Singer SJ, Eastman D, Li Z, Schneider EC. Effect of a multipayer patient-centered medical home on health care utilization and quality: the Rhode Island chronic care sustainability initiative pilot program. JAMA Intern Med. 2013;173(20):1907-1913.

18. Friedberg MW, Schneider EC, Rosenthal MB, Volpp KG, Werner RM. Association between participation in a multipayer medical home intervention and changes in quality, utilization, and costs of care. JAMA. 2014;311(8):815-825.

19. Schneider, EC. Strengthening Primary Care Amid the Hype. The Commonwealth Fund. http://www.commonwealthfund.org/publications/blog/2015/jun/strengthening-primary-care-amid-the-hype. Published Jun 1, 2015. Accessed Jul 15, 2015.

20. Landon BE. Structuring payments to patient-centered medical homes. JAMA. 2014;312(16):1633-1634. 
21. Saultz JW, Jones SM, McDaniel SH, et al. A new foundation for the delivery and financing of American health care. Fam Med. 2015;47 (8):612-619.

22. Basu S, Landon BE, Song Z, Bitton A, Phillips RS. Implications of workforce and financing changes for primary care practice utilization, revenue, and cost: a generalizable mathematical model for practice management. Med Care. 2015;53(2):125-132.

23. Basu S, Phillips RS, Bitton A, Song Z, Landon BE. Medicare chronic care management payments and financial returns to primary care practices. Ann Intern Med. 2015;163(8):580-588.

24. US Census Bureau. Current Population Survey: Annual Social and Economic Supplements. Washington, DC: US Census Bureau; 2013.

25. Agency for Healthcare Research and Quality. Medical Expenditure Panel Survey. Washington, DC: AHRQ; 2013.

26. Medical Group Management Association. DataDive. Englewood, CO: MGMA; 2015

27. Bureau of Labor Statistics. Employer Costs for Employee Compensation. http://www.bls.gov/news.release/ecec.toc.htm. Published 2014. Accessed Jul 21, 2013. Updated Jun 9, 2016.

28. Kenexa IBM. CompAnalyst Market Data. Armonk, NY: IBM; 2015.

29. CareFirst BlueCross BlueShield. Patient-Centered Medical Home Program Shows Promising Quality Trends and Continued Savings on Expected Costs. Baltimore: BlueCross BlueShield; 2014.

30. Center for Connected Health Policy. State Telehealth Policies and Reimbursement Schedules: A Comprehensive Plan of the 50 States and District of Columbia. Sacramento, CA: CCHP; 2014

31. Neufeld J. Telehealth Costs, Business Models, Risks, and Savings Strategies. Terra Haute, IN: Upper Midwest Telemedicine Resource Center; 2015.

32. Scott A, Sivey $P$, Ait Ouakrim D, et al. The effect of financial incentives on the quality of health care provided by primary care physicians. Cochrane Database Syst Rev. 2011; 7(9):CD008451.

33. Congressional Budget Office. Effects of the Affordable Care Act on Health Insurance Coverage - Baseline Projections. Washington, DC: CBO; 2015. https://www.cbo.gov/publication/43900. Accessed Feb $12,2015$.

34. Basu S, Landon B, Song Z, Bitton A, Phillips R. Implications of workforce and financing changes for primary care practice utilization, revenue, and cost: a generalizable mathematical model for practice management. Med Care. 2015;53(2):125-132.

35. Bureau of Labor Statistics. Consumer Price Index (CPI). http://www. bls.gov/cpi/. Published 2014. Accessed Sep 26, 2013.

36. Centers for Disease Control and Prevention. National Ambulatory Medical Care Survey (NAMCS). Atlanta, GA: CDC; 2014.

37. Medical Group Management Association. Cost Survey for SingleSpecialty Practices. Englewood, CO: MGMA; 2014.

38. Nocon RS, Sharma R, Birnberg JM, Ngo-Metzger Q, Lee SM, Chin $\mathrm{MH}$. Association between patient-centered medical home rating and operating cost at federally funded health centers. JAMA. 2012;308(1):60-66.

39. Martsolf GR, Kandrack R, Gabbay RA, Friedberg MW. Cost of transformation among primary care practices participating in a medical home pilot. J Gen Intern Med. 2016;31(7):723-731.

40. Peikes DN, Reid RJ, Day TJ, et al. Staffing patterns of primary care practices in the comprehensive primary care initiative. Ann Fam Med. 2014;12(2):142-149.

41. Magill MK, Ehrenberger D, Scammon DL, et al. The cost of sustaining a patient-centered medical home: experience from 2 states. Ann Fam Med. 2015;13(5):429-435.

42. Centers for Medicare $\&$ Medicaid Services. Summary of policies in the calendar year (CY) 2015 Medicare Physician Fee Schedule (MPFS) final rule and telehealth originating site facility fee payment amount. MM9034. MLN Matters. https://www.cms.gov/Outreachand-Education/Medicare-Learning-Network-MLN/MLNMatters Articles/downloads/MM9034.pdf. Revised Jan 18, 2015.
43. Nocedal J, Wright SJ. Numerical Optimization. New York, NY: Springer Science+ Business Media; 2006.

44. Basu S, Andrews J. Complexity in mathematical models of public health policies: a guide for consumers of models. PLoS Med. 2013;10(10):e1001540.

45. Pope GC, Ellis RP, Ash AS, et al. Diagnostic cost group hierarchical condition category models for Medicare risk adjustment. Centers for Medicare and Medicaid Services. https://www.cms.gov/ResearchStatistics-Data-and-Systems/Statistics-Trends-and-Reports/Reports/ Downloads/Pope_2000_2.pdf. Published Dec 21, 2000. Accessed Oct 26, 2015

46. Steele GD, Haynes JA, Davis DE, et al. How Geisinger's advanced medical home model argues the case for rapid-cycle innovation. Health Aff (Millwood). 2010;29(11):2047-2053.

47. Sessums LL, McHugh SJ, Rajkumar R. Medicare's vision for advanced primary care: New directions for care delivery and payment. JAMA. 2016;315(24):2665-2666.

48. Christensen EW, Dorrance KA, Ramchandani S, et al. Impact of a patient-centered medical home on access, quality, and cost. Mil Med. 2013;178(2):135-141.

49. Coleman K, Reid RJ, Johnson E, et al. Implications of reassigning patients for the medical home: a case study. Ann Fam Med. 2010; $8(6): 493-498$

50. Driscoll DL, Hiratsuka V, Johnston JM, et al. Process and outcomes of patient-centered medical care with Alaska Native people at Southcentral Foundation. Ann Fam Med. 2013;11(Suppl 1):S41-S49.

51. Fillmore H, DuBard CA, Ritter GA, Jackson CT. Health care savings with the patient-centered medical home: Community Care of North Carolina's experience. Popul Health Manag. 2014;17(3):141-148.

52. Flottemesch TJ, Anderson LH, Solberg LI, Fontaine P, Asche SE. Patient-centered medical home cost reductions limited to complex patients. Am J Manag Care. 2012;18(11):677-686.

53. Gilfillan RJ, Tomcavage J, Rosenthal MB, et al. Value and the medical home: effects of transformed primary care. Am J Manag Care. 2010;16(8):607-614.

54. Maeng DD, Graham J, Graf TR, et al. Reducing long-term cost by transforming primary care: evidence from Geisinger's medical home model. Am J Manag Care. 2012;18(3):149-155.

55. Milstein A, Gilbertson E. American medical home runs. Health Aff (Millwood). 2009;28(5):1317-1326.

56. Phillips RL Jr, Bronnikov S, Petterson S, et al. Case study of a primary care-based accountable care system approach to medical home transformation. J Ambul Care Manage. 2011;34(1):67-77.

57. Reid RJ, Johnson EA, Hsu C, et al. Spreading a medical home redesign: effects on emergency department use and hospital admissions. Ann Fam Med. 2013;11(Suppl 1):S19-S26.

58. Roby DH, Pourat N, Pirritano MJ, et al. Impact of patient-centered medical home assignment on emergency room visits among uninsured patients in a county health system. Med Care Res Rev. 2010;67(4):412-430.

59. Rosenberg CN, Peele P, Keyser D, McAnallen S, Holder D. Results from a patient-centered medical home pilot at UPMC Health Plan hold lessons for broader adoption of the model. Health Aff (Millwood). 2012;31(11):2423-2431.

60. Steiner BD, Denham AC, Ashkin E, Newton WP, Wroth T, Dobson LA Jr. Community care of North Carolina: improving care through community health networks. Ann Fam Med. 2008;6(4):361-367.

61. Takach M. Reinventing Medicaid: state innovations to qualify and pay for patient-centered medical homes show promising results. Health Aff (Millwood). 2011;30(7):1325-1334.

62. Mathematica Policy Research. Evaluation of the Comprehensive Primary Care Initiative: First Annual Report. Princeton, NJ: Mathematica Policy Research; 2015. 
63. Jerant A, Bertakis KD, Fenton JJ, Franks P. Extended office hours and health care expenditures: a national study. Ann Fam Med. 2012;10(5):388-395.

64. Day J, Scammon DL, Kim J, et al. Quality, satisfaction, and financial efficiency associated with elements of primary care practice transformation: preliminary findings. Ann Fam Med. 2013;11(Suppl 1):S50-S59.

65. Fishman PA, Johnson EA, Coleman K, et al. Impact on seniors of the patient-centered medical home: evidence from a pilot study. Gerontologist. 2012;52(5):703-711.

66. Gabbay RA, Bailit MH, Mauger DT, Wagner EH, Siminerio L. Multipayer patient-centered medical home implementation guided by the chronic care model. Jt Comm J Qual Patient Saf. 2011;37(6): 265-273.

67. Lee K, Palacio C, Alexandraki I, Stewart E, Mooradian AD. Increasing access to health care providers through medical home model may abolish racial disparity in diabetes care: evidence from a crosssectional study. J Natl Med Assoc. 2011;103(3):250-256.
68. Meyer H. Group Health's move to the medical home: for doctors, it's often a hard journey. Health Aff (Millwood). 2010;29(5):844-851. 69. Rankin KM, Cooper A, Sanabria K, Binns HJ, Onufer C. Illinois medical home project: pilot intervention and evaluation. Am J Med Qual. 2009;24(4):302-309.

69. Rankin KM, Cooper A, Sanabria K, Binns HJ, Onufer C. Illinois medical home project: pilot intervention and evaluation. Am J Med Qual. 2009;24(4):302-309..

70. Reid RJ, Coleman K, Johnson EA, et al. The Group Health medical home at year two: cost savings, higher patient satisfaction, and less burnout for providers. Health Aff (Millwood). 2010;29(5):835-843.

71. Solberg LI, Asche SE, Fontaine P, Flottemesch TJ, Anderson LH. Trends in quality during medical home transformation. Ann Fam Med. 2011;9(6):515-521.

72. Solimeo SL, Hein M, Paez M, Ono S, Lampman M, Stewart GL. Medical homes require more than an EMR and aligned incentives. Am J Manag Care. 2013;19(2):132-140.

\section{Get the Annals of Family Medicine by E-mail}

Make sure you see every new issue

while it's fresh; have the table of

contents sent to you by e-mail for

easy access to articles of interest.

Don't miss important research.

Request the e-mail table of contents at

http://www2.highroadsolution.com/

aafp_annals_preference_center/search.aspx
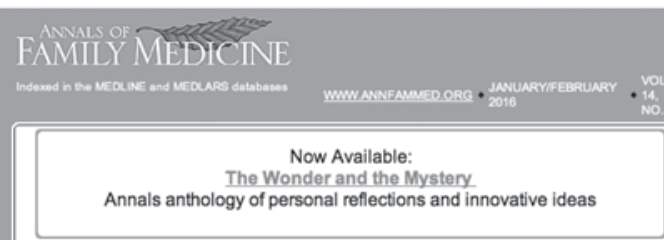

The full text of the journal is avaliable online at htho thumw annfammed, sog and through various

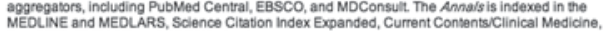
PSyCINFO, EMBASE, and CINHAL databases

EDITORIALS

In This Issue: Size Natters

Achieving PCMH Stans May Not Be Meaningtul for Small Practices
Kelley K. Glancey; James Q Konnedy The Paradox of Size: How Small, Independent Practices Can Thrive in Value-Based Care
Farzad Mostashart

ORIGINAL RESEARCH

Solo and Small Practices: A Vital, Diverse Part of Primary Care

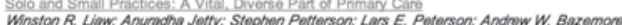
Family physicians in solo and small practices outnumber those in larger practices.

Large Indogandent Primay Caro Medical Groura

Lawrence P. Casalino; Melinda A. Chen; C. Todd Staub; Matthew J. Press; Jayme L

政

Primary Care Physiclian Panel Size and Quality of Care: A Pooulation-Based Study in Ontario. Simone Dahrouge; Wiwiam Hogg: Jaime Younger, Elizabech Muggan; Grant Russell; Richard H.

In Ontario, larger patient panel sizes do not decrease quality of care, but cancer screening rates are slightly lower.

Willingness to Exchange Health Information via Mobile Devices: Findings From a Kopulation-Based Survey Marchesin', Audie A. Atienzs

Willingness to exchange health information via mobilo devices varies with the sensitivity of the 